\title{
BAHASA ARAB UNTUK PENDIDIKAN AWAL KANAK-KANAK: SATU KAJIAN ANALISIS KEPERLUAN
}

\author{
Arabic for Early Childhood Education: A Need Analysis Study
}

\author{
Mohammad Taufiq Abdul Ghani ${ }^{1}$, Wan Ab Aziz Wan Daud ${ }^{2}$ \\ Fakulti Bahasa dan Komunikasi, \\ Universiti Pendidikan Sultan Idris, Tanjong Malim, Perak, Malaysia ${ }^{1}$, \\ Universiti Malaysia Kelantan ${ }^{2}$ \\ taufiq@fbk.upsi.edu.my ${ }^{1}$, abaziz.wd@umk.edu.my²
}

\begin{abstract}
ABSTRAK
Pembelajaran bahasa penting untuk pendidikan awal kanak-kanak di negara yang pelbagai budaya seperti Malaysia. Justeru, guru prasekolah memainkan peranan penting dalam melaksanakan pendidikan pembelajaran bahasa di dalam kelas. Pembelajaran bahasa, khususnya bahasa Arab telah mendapat perhatian dalam kalangan pendidik pada masa kini. Oleh itu, penyelidikan ini menerangkan keperluan dan kepentingan bahasa Arab dalam bidang pendidikan awal kanak-kanak. Soal selidik telah digunakan sebagai instrumen untuk mengumpul data. Borang Soal selidik tertutup telah diedarkan kepada 80 orang pelajar yang mengikuti kursus diploma dalam pendidikan awal kanak-kanak di Kolej Poly-Tech MARA (KPTM), Kota Bharu, Kelantan manakala boring soal selidik terbuka telah diedarkan kepada tujuh (7) orang guru prasekolah di Kota Bharu untuk meneroka kepentingan bahasa Arab dalam kalangan pendidik kanak-kanak. Analisis kuantitatif deskriptif digunakan untuk menganalisis data melalui penggunaan perisian statistik IBM SPSS. Secara keseluruhannya hasil kajian mendapati bahawa keupayaan untuk memahami istilah-istilah asas yang berkaitan dengan pendidikan awal kanak-kanak merupakan salah satu keperluan yang penting bagi pelajar pendidikan awal kanak-kanak di Kolej Poly-Tech Mara (KPTM). Keadaan ini berlaku kerana istilah berkenaan digunakan oleh pelajar-pelajar dalam pengajian dan di alam pekerjaan kerana mereka dikehendaki mengajar bahasa Arab di prasekolah. Di samping itu, kemahiran bahasa Arab juga memberikan kelebihan dan nilai tambah kepada mereka kerana dapat meningkatkan kemahiran komunikasi seterusnya dapat mengaplikasikannya dalam pengendalian kelas.
\end{abstract}

Kata kunci: Bahasa Arab untuk tujuan khusus, bahasa Arab, pendidikan awal kanak-kanak, pembelajaran bahasa, analisis keperluan.

\begin{abstract}
Language learning is necessary for early childhood education in a culturally diverse country like Malaysia. In this regard, pre-school teachers play an important role in implementing language learning education in the classroom. Language learning, especially Arabic language has gained attention among educators nowadays. Hence, this research explores the need and the significance of Arabic language in the field of early childhood education. Questionnaire was adopted as a research tool for data collecting. The close-ended questionnaire wss administrated to 80 students studying for a diploma in early childhood education in MARA Poly-Tech College (KPTM), Kota Bharu, Kelantan and open-ended questionnaire was distributed among seven (7) pre-school teachers to explore the significance of Arabic language to early childhood educators. Descriptive quantitative analysis was employed to analyze the data through the use of IBM SPSS statistical software. In general, the study found that developing the capacity to understand the basic terms related to early childhood education is one of the most important needs of early childhood education student at the Mara College of Poly-tech (KPTM), as these terms are used by the students in their studies and in their workplace where they are required to teach Arabic in kindergarten. In addition, Arabic language proficiency also provides value added advantage from them as they can improve their communication skill and use them in the classroom.
\end{abstract}

Keywords: arabic for specific purpose, Arabic language, early childhood education, language learning, need analysis. 


\section{PENGENALAN}

Bahasa merupakan elemen penting dalam kehidupan manusia. Manusia dapat memenuhi tuntutan kehidupan masing-masing melalui media komunikasi dengan menguasai bahasa. Pengajaran Bahasa Arab semakin berkembang di Malaysia menjelang abad ke-21. Semakin banyak institusi pengajian tinggi awam dan swasta yang menyediakan pembelajaran bahasa Arab sama ada dalam bentuk penawaran program atau mata pelajaran bahasa Arab. Akta pendidikan 1996 telah menetapkan bahawa kursus bahasa Arab secara rasmi dimasukkan ke dalam kurikulum pendidikan Malaysia sebagai bahasa asing dan diajar ke sekolah-sekolah. Banyak institusi pengajian tinggi menawarkan kursus bahasa Arab sebagai kursus elektif kepada pelajar kerana wujudnya kesedaran akan kepentingan bahasa ketiga. Lazimnya, pelajar mempunyai persepsi yang negatif terhadap bahasa Arab. Hal ini kerana, silibus dan bahan pengajaran tidak mencapai standard dan keperluan pelajar. Keperluan pelajar perlu diambil kira dalam proses pengajaran dan pembelajaran supaya dapat mengekalkan tahap motivasi dan minat pelajar dalam mempelajari bahasa Arab. Kajian ini adalah untuk meninjau kepentingan dan keperluan bahasa Arab dalam kalangan pelajar jurusan pendidikan awal kanak-kanak di Kolej Poly-Tech Mara, Kota Bharu Kelantan.

\section{LATAR BELAKANG KAJIAN}

Bahasa Arab ialah bahasa kelima yang paling banyak digunakan di dunia dengan lebih 300 juta penutur. Bahasa Arab merupakan bahasa rasmi di 20 buah negara dan untuk Pertubuhan Bangsa-bangsa Bersatu, Liga Arab, Pertubuhan Persidangan Islam dan Kesatuan Afrika. Permintaan untuk bahasa Arab dengan bahasa dwibahasa atau berbilang bahasa dalam karier seperti kewartawanan, perniagaan dan industri, pendidikan, penterjemahan dan tafsiran, perundingan telah menegaskan lagi kedudukannya sebagai bahasa kepentingan strategik. Dalam konteks Malaysia, bahasa Arab dianggap sebagai bahasa kedua yang sama dengan bahasa Inggeris. Bahasa Arab juga boleh dianggap sebagai bahasa ketiga atau bahasa asing. Sejak sekolah agama dan institusi agama diperkenalkan, Bahasa Arab menjadi salah satu bahasa yang paling penting di Malaysia kerana bahasa ini digunakan untuk membaca dan memahami buku agama dan sumber-sumber agama yang kebanyakannya ditulis dalam bahasa Arab. Kurikulum pada masa kini, Kementerian Pendidikan Malaysia memperkenalkan Bahasa Arab sebagai subjek di sekolah rendah untuk membolehkan murid belajar dan memperbaiki bahasa Arab seiring dengan empat kemahiran fokus; mendengar, bercakap, menulis dan membaca.

Pendidikan bahasa Arab sebagai bahasa kedua terdapat di sekolah menengah dan beberapa universiti yang mempunyai Fakulti Pengajian Islam, Jabatan Bahasa Arab atau Jabatan Bahasa Moden/ Asing. Pelajar sentiasa mendengar perkataan dalam bahasa Arab, memahami makna dan mengulangi beberapa ungkapan bahasa Arab setiap hari (Shamsuddin \& Ahmad, 2017). Walau bagaimanapun, majoriti pelajar tidak dapat menggunakan bahasa Arab di dalam dan di luar bilik darjah. Menurut Awang et al., (2013) pelajar tidak mempunyai keyakinan untuk menutur bahasa Arab dan faktor ini akan meruntuhkan motivasi mereka untuk menjadi penutur bahasa Arab yang baik. Meyad et al. (2014) menegaskan bahawa motivasi ialah faktor penting dalam pembelajaran bahasa kedua atau bahasa asing tanpa mengira bahasa bahasa yang rumit. Berdasarkan kenyataan di atas, pentingnya mata pelajaran Bahasa Arab diajar diperingkat awal bagi kanak-kanak kerana bahasa Arab merupakan bahasa yang sangat hampir dengan masyarakat Malaysia terutamanyan dalam perspektif Islam. Perkataan pendidikan juga dirujuk daripada perkataan Arab iaitu taalim, tarbiyah dan ta'dib. Dalam 
konteks ini, kepentingan bahasa Arab dalam bidang pendidikan Awal Kanak-kanak membantu para pelajar memahami asas - asas Islam yang sumber utamanya adalah daripada bahasa Arab dan sebagai persediaan awal kepada pelajar untuk menjalani kelas Jawi, al-Quran, Arab dan Fardhu Ain (JQAF) dan Kelas al-Quran dan Fardhu Ain (KAFA).

\section{Bahasa Arab Bagi Tujuan Khas}

Bahasa telah berkembang menjadi bahasa untuk tujuan khusus pada pertengahan abad ke 20 . Bahasa yang mempelopori dalam bidang ini ialah bahasa Inggeris yang merupakan antara bahasa utama dunia. Menyedari betapa pentingnya bahasa Arab kepada komuniti global, sesetengah penyelidik telah mengambil langkah-langkah untuk mengkaji bidang bahasa tertentu yang kemudian menunjukkan relevan dalam kajian bahasa Arab untuk keperluan khusus (Chik, 1988). Abdul Rahman Chik (1988) menyedari bahawa minat mendalam terhadap pembangunan bahasa untuk tujuan khusus telah mula muncul pada tahun enam puluhan abad yang lalu, apabila sekumpulan pakar dalam bidang linguistik yang menganalisis bidang bahasa yang berbeza. Mereka mendapati bahawa setiap perbendaharaan kata, peraturan dan kaedah berbeza mengikut bidang. Kompleks bahasa untuk tujuan khas bergantung kepada pengkhususan dan kepakaran para pelajar. Terdapat akademi bahasa untuk pelbagai tujuan khusus iaitu: profesional, agama, komersial, perubatan, saintifik, undang-undang, dan media, termasuk semua bidang pendidikan dan profesional (Chik, 2007).

Hutchinson dan Waters (2001) merumuskan konsep bahasa untuk tujuan khas sebagai "Pendekatan pengajaran bahasa di mana semua keputusan mengenai kandungan dan kaedah adalah berdasarkan kepada keperluan pembelajaran pelajar". Oleh itu, tumpuan kepada keperluan pelajar menjadi sama pentingnya dengan kaedah yang digunakan untuk menyebarkan pengetahuan linguistik. Merancang kursus khusus untuk memenuhi keperluan individu ini lebih baik daripada pendapat ini. Sehingga hari ini, kata kunci dalam bahasa Arab untuk tujuan khusus adalah berpusatkan pelajar atau berpusatkan pembelajaran.

Berdasarkan pandangan Muhammad Najib Jaafar (2014), terdapat tiga jenis bahasa Arab iaitu bagi tujuan khusus; 1) Bahasa Arab untuk Tujuan Profesional, 2) Bahasa Arab untuk Tujuan Akademik, 3) Bahasa Arab dengan topik tertentu.

Muhammad Najib Jaffar (2014) telah menyatakan bahawa tidak ada perbezaan jelas antara Bahasa Arab untuk Tujuan Akademik dan Bahasa Arab untuk Tujuan Pekerjaan. Pelajar boleh bekerja dan belajar secara serentak. Mereka juga boleh mempelajari bahasa dan mengaplikasikannya ke dalam persekitaran pengajian atau mengaplikasikannya apabila kembali ke bidang pekerjaan.

Rushdi Ahmad Tua'imat (2003) menggambarkan kelebihan utama pembelajaran bahasa untuk tujuan khusus yang mempunyai metodologi yang jelas yang perlu dipatuhi bagi memastikan kecekapan prestasi dan kualiti hasil. Selain itu, program ini juga dapat meningkatkan produktiviti pelajar dalam kariernya kerana pengajaran tertumpu pada kecekapan dalam mempelajari konsep dan terminologi yang lazim dalam bidangnya seterusnya mampu meningkatkan kejayaan peluang pelajar dan keupayaannya untuk mencapai kejayaan dalam program ini. Program ini juga mampu meningkatkan motivasi pelajar kerana mereka belajar sesuatu yang mencapai keperluan dan kehendak mereka dalam kehidupan.

Sebagaimana yang disarankan oleh para pengkaji, pendidikan bahasa Arab bagi tujuan khas seperti bahasa Arab untuk pendidikan awal kanak-kanak perlu diperkenalkan. Kesedaran akan kepentingan bahasa Arab bagi pelajar jurusan pendidikan awal pendidikan awal kanak- 
kanak perlu dibentuk terlebih dahulu. Dengan terbentuknya kesedaran ini, maka akan lahirlah usaha-usaha kearah memperkasakan bahasa Arab bagi tujuan pendidikan awal kanak-kanak yang akan membawa kepada kejayaan dan nilai tambah kepada bakal pendidik. Banyak kajian yang telah dijalankan mengenai kepentingan dan keberkesanan bahasa Arab bagi tujuan khas ini seperti Bahasa Arab untuk pelancongan (Taufiq, 2016), Bahasa Arab untuk kewangan Islam (Najmiyyah, 2009), bahasa Arab untuk kejururawatan (Ghazali, 2010), Bahasa Arab untuk sains (Ashikin, 2012) dan bahasa Arab untuk pertanian (Aziz, 2016). Berdasarkan kepada kajian - kajian berikut, penyelidik berpandangan bahawa mata pelajaran bahasa Arab untuk pendidikan awal kanak-kanak perlu diperkenalkan kerana bidang pendidikan awal kanakkanak lebih dekat dan sinonim dengan bahasa Arab. Selain itu, mata pelajaran bahasa Arab juga masih belum dimasukkan secara menyeluruh ke dalam struktur program Pendidikan Awal Kanak-Kanak di Malaysia. Justeru itu, kajian ini mengetengahkan kepentingan bahasa Arab bagi program Pendidikan Awal Kanak-Kanak.

\section{SOROTAN LITERATUR}

Pada tahun 2005, Abdul Halim Salleh meneliti keperluan jemaah haji untuk merancang modul khas untuk mengajar bahasa Arab untuk tujuan Haji dan Umrah. Penulis mengkaji faktor utama yang menggalakkan jemaah haji belajar bahasa Arab sama ada untuk tujuan agama, memahami budaya Arab, urusan ekonomi atau bersosial. Modul ini juga direka bentuk dengan memasukkan elemen kemahiran bertutur kerana ia merupakan kemahiran yang paling penting digunakan oleh jemaah haji dan umrah.

Najmiah (2009) yang menjalankan kajian terhadap bahasa Arab untuk ekonomi dengan menganalisis keperluan khas untuk pelajar jurusan ekonomi, dan seterusnya mereka bentuk satu modul khusus yang membantu mereka memahami rujukan Arab yang berkaitan dengan bidang ekonomi. Penyelidik menggunakan pendekatan berpusatkan pembelajaran dalam modul bahasa Arab bagi tujuan khusus seperti yang dicadangkan oleh Hutchinson dan Waters (1987). Kajian ini mendapati bahawa kemahiran bahasa iaitu bertutur, mendengar, membaca dan menulis adalah penting dalam pendidikan bahasa Arab untuk ekonomi. Penemuan kajian ini menunjukkan bahawa majoriti pelajar ekonomi memilih untuk memperoleh kemahiran membaca berbanding dengan kemahiran bahasa lain yang membantu mereka memahami, menilai, dan mengimbas teks yang berkaitan dengan bidang.

Pada tahun 2010, Ghazali Zainuddin telah merancang modul pembelajaran bahasa Arab bagi tujuan kejururawatan di Hospital Putrajaya dan pelajar bagi program kejururawatan di Kolej Universiti Islam Antarabangsa Selangor (KUIS). Penyelidik menimbulkan kebimbangan mengenai keperluan bahasa untuk profesional dan pendidikan. Berdasarkan analisis keperluan yang dibuat oleh penyelidik, hasilnya melaporkan terdapat percanggahan dalam keperluan bahasa untuk para profesional dan pelajar. Pelajar kejururawatan memilih kemahiran bertutur diikuti dengan membaca, menulis dan mendengar. Sebaliknya, jururawat memilih kemahiran bertutur diikuti dengan mendengar, membaca dan menulis. Menurut penyelidik, jururawat di sektor profesional menggunakan bahasa Arab untuk bercakap dan mendengar ketika mereka memeriksa pesakit berbangsa Arab.

Aiman Ismail (2012) menjelaskan bahawa kursus bahasa Arab bagi tujuan khusus mesti menampung tahap pelajar serta topik dalam kursus itu yang bersesuaian dengan keperluan pelajar. Modul khas telah direka oleh penyelidik untuk mengajar kemahiran membaca untuk tujuan sains dengan memperkenalkan kosa kata dan struktur bahasa melalui kaedah 
pemprosesan dan penggunaan. Objektif utama kajian ini adalah untuk mengenal pasti keperluan pelajar, menganalisis perbincangan yang berkaitan dengan fiksyen sains daripada rujukan bahasa Arab dan reka bentuk modul yang sesuai dalam pembelajaran kemahiran membaca untuk tujuan sains.

Pada tahun 2015, Abdul Hadi Abdul Rahim bersama rakan penyelidiknya telah menganalisis keperluan pelajar undang-undang syariah dalam mempelajari bahasa Arab di Universiti Islam Antarabangsa Malaysia (UIAM). Majoriti para pelajar mempunyai pandangan positif dalam mempelajari bahasa Arab untuk memahami al-Quran dan Hadis kerana keduaduanya merupakan rujukan utama dalam bidang perundangan syariah. Penulis menemui masalah yang dihadapi oleh pelajar dalam mempelajari bahasa Arab iaitu bilangan pelajar di dalam kelas menyumbang penurunan motivasi pelajar untuk belajar dan menutur bahasa Arab. Penyelidik mencadangkan pengamal bahasa Arab bagi tujuan khusus untuk menyelesaikan masalah yang dihadapi oleh pelajar sebelum mereka bentuk modul yang ideal dan juga untuk mewujudkan persekitaran Arab di dalam kelas yang berkaitan dengan kemahiran bahasa bagi meningkatkan motivasi dan keyakinan diri mereka dalam mempraktikkan Bahasa Arab.

Dalam satu kajian yang dijalankan oleh Wan Ab Aziz Wan Daud (2016) di KPTM, penulis mencadangkan kursus bahasa Arab bagi tujuan khusus untuk pelajar diploma dalam bidang Agro Teknologi. Analisis keperluan khas telah dijalankan oleh (Daud \& Ghani, 2016) untuk mengenal pasti keperluan pelajar di mana pelajar lebih suka mempelajari kosa kata dan corak bahasa yang berkaitan dengan bidang. Selain itu pelajar lebih suka kemahiran bertutur berbanding dengan kemahiran bahasa yang lain kerana mereka merasakan penggunaan kemahiran ini akan dipraktikan untuk kerjaya mereka di lapangan.

Pada tahun 2013 Zalika merancang dan membangunkan modul bahasa Arab untuk bidang pelancongan. Analisis keperluan khas dilakukan di kalangan profesional (Adam \& Chik, 2011) untuk mengenal pasti dan mengkaji keperluan, dan untuk meneliti pendapat dan cadangan yang memberi manfaat kepada pelajar. 292 profesional dari pelbagai sektor mengambil bahagian dalam fasa analisis keperluan. Kajian mendapati kemahiran bertutur ialah kemahiran bahasa yang paling penting dalam industri pelancongan. Menariknya, penulis juga menemui keperluan dalam menguasai dialek Arab terutamanya dialek Arab Saudi dan dialek Mesir.

Dalam satu lagi kajian, Taufiq dan Sabri (2016) merancang dan membangunkan laman web khas untuk mempelajari bahasa Arab untuk tujuan pelancongan. Laman web ini direka bentuk dengan menggunakan Joomla sebagai platform untuk pembangunan laman web bersama dengan penerapan model pengajaran ADDIE. Laman web ini direka berdasarkan analisis keperluan pelajar, pendapat, dan cadangan pelajar jurusan pelancongan. Kajian ini mendedahkan bahawa majoriti pelajar optimis mempelajari bahasa Arab untuk tujuan pelancongan melalui laman web yang menggalakkan dan memotivasi mereka untuk mempelajari bahasa Arab kerana dapat menawarkan mereka peluang untuk memparktis pembelajaran kendiri.

Umumnya, terdapat sejumlah sorotan literatur yang menggambarkan bahasa Arab bagi tujuan khusus. Kajian terdahulu menumpu pada reka bentuk modul dan perisian khusus untuk mengajar bahasa Arab Bagi tujuan khusus berdasarkan analisis keperluan pelajar. Untuk memastikan keberkesanan kursus bahasa Arab bagi tujuan khusus, para pengamal harus melibatkan fasa analisis keperluan dalam merancang isi modul, memilih kosa kata yang berkaitan dengan bidang dan corak bahasa yang sesuai, serta memilih pedagogi bahasa yang bersesuaian. Semua kajian terdahulu yang disebutkan di atas memberi tumpuan kepada 
pelbagai bidang seperti ekonomi, kejururawatan, sains, dan bidang-bidang yang lain. Oleh itu, kertas penyelidikan ini memberi tumpuan kepada bidang yang baharu iaitu bahasa Arab untuk pendidikan awal kanak kanak memandangkan ia masih di peringkat awal dalam penyelidikan dan semakin manarik minat dan perhatian para penyelidik.

Berdasarkan kepada kepentingan bahasa Arab bagi tujuan khusus, khususnya bagi tujuan pendidikan awal kanak-kanak untuk memastikan para pengamal pendidikan awal kanakkanak mempunyai nilai tambah dalam komunikasi bahasa terutama bahasa Arab sebagai bahasa kedua. Kepentingan Bahasa Arab bagi tujuan pendidikan awal kanak-kanak akan membantu para pendidik dalam proses pengajaran dan pembelajaran di dalam kelas kerana setiap guru pendidikan awal kanak-kanak akan mengajar setiap mata pelajaran yang terdapat di sekolah. Sebagai seorang bakal pendidik kanak-kanak, mereka seharusnya mempunyai pengetahuan yang luas mengenai ilmu bahasa Arab yang merupakan tunjang utama pendidikan Islam. Berdasarkan pemerhatian penyelidik mendapati tiada kajian secara mendalam mengenai kepentingan dan keperluan mata pelajaran bahasa Arab bagi pelajaran jurusan Pendidikan Awal kanak-kanak di peringkat diploma mahupun sarjana muda.

Kemampuan guru pendidikan awal kanak-kanak untuk bertutur dalam bahasa sasaran juga merupakan satu keperluan yang penting khususnya dalam melaksanakan aktiviti-aktiviti pengajaran dan pemudahcaraan $(\mathrm{PdPc})$ di dalam kelas. Sekiranya guru mempunyai kemampuan yang terbatas, beliau tidak akan mampu membantu dan menjalankan proses PdPc dengan berkesan. Oleh yang demikian, pihak institusi seharusnya menawarkan matapelajaran bahasa Arab sebagai matapelajaran minor atau elektif.

\section{METODOLOGI}

Kajian diskriptif kuantitatif digunakan untuk menerangkan secara ringkas bahasa Arab untuk tujuan khusus dan menganalisis kepentingan bahasa Arab untuk pendidikan awal kanak-kanak. Soal selidik telah dipilih sebagai kaedah pengumpulan data untuk mengukur keperluan dan kepentingan pembelajaran bahasa Arab untuk tujuan pendidikan awal kanak-kanak. Satu set soal selidik telah diedarkan kepada 80 pelajar jurusan pendidikan awal kanak-kanak dan 7 orang guru pendidikan awal kanak-kanak untuk meneroka keperluan dan kepentingan bahasa Arab kepada bidang ini. Set soal selidik kepada pelajar menggunakan 5 skala Likert bermula dari satu (Sangat Tidak Setuju) hingga 5 (Sangat Setuju) manakala soal selidik kepada guru menggunakan soalan terbuka. Analisis diskriptif kuantitatif digunakan untuk menganalisis data dengan menggunakan perisian IBM SPSS versi 22.

\section{ANALISIS DAN PERBINCANGAN}

Tujuan utama kajian ini adalah untuk meneroka keperluan dan kepentingan bahasa Arab dalam kalangan pelajar jurusan pendidikan awal kanak-kanak. Hasil dan penemuan dilaporkan dalam dua kategori utama, yang merupakan keperluan dan kepentingan dari perspektif pelajar dan perspektif guru. Butiran terperinci adalah seperti berikut.

\section{Bahagian A: Perspektif Pelajar}

Bahagian ini merangkumi latar belakang responden yang terdiri daripada enam item dan keperluan bahasa Arab dalam kalangan perspektif pelajar pendidikan awal kanak-kanak yang mengandungi tujuh item. 
Jadual 1: Latar Belakang Demografik

\begin{tabular}{|c|c|c|c|c|}
\hline \multicolumn{3}{|c|}{ Latar Belakang Demografik } & Frekuensi (N) & Peratusan $(\%)$ \\
\hline \multirow{2}{*}{1.} & \multirow{2}{*}{ Jantina } & Lelaki & 6 & 7.5 \\
\hline & & Perempuan & 74 & 92.5 \\
\hline 2. & Pengkhususan & $\begin{array}{ll}\text { Pendidikan } & \text { Awal } \\
\text { Kanak-Kanak } & \end{array}$ & 80 & 100 \\
\hline \multirow{4}{*}{3.} & \multirow{4}{*}{ Tahun Pengajian } & Tahun 1 & 25 & 31.3 \\
\hline & & Tahun 2 & 22 & 27.5 \\
\hline & & Tahun 3 & 33 & 41.3 \\
\hline & & Tahun 4 & 0 & 0 \\
\hline \multirow{3}{*}{4.} & \multirow{3}{*}{ Bahasa Utama } & Melayu & 79 & 98.8 \\
\hline & & Mandrin & 1 & 1.3 \\
\hline & & Tamil & 0 & 0 \\
\hline \multirow{2}{*}{5 . } & \multirow{2}{*}{ Latar Belakang Bahasa Arab } & $\mathrm{Ya}$ & 48 & 60 \\
\hline & & Tidak & 32 & 40 \\
\hline \multirow{5}{*}{6.} & \multirow{5}{*}{$\begin{array}{l}\text { Tempoh Pengajian Bahasa } \\
\text { Arab }\end{array}$} & 0 Tahun & 32 & 40 \\
\hline & & 1-2 Tahun & 13 & 16 \\
\hline & & 2-3Tahun & 13 & 16 \\
\hline & & 3-4 Tahun & 13 & 16 \\
\hline & & 4-5 Tahun & 12 & 12 \\
\hline
\end{tabular}

Seperti yang ditunjukkan dalam Jadual 1, majoriti responden ialah pelajar perempuan (92.5\%) manakala bakinya ialah pelajar lelaki (7.5\%). Pelajar tersebut merupakan pelajar program pendidikan awal kanak-kanak di KPTM, Kota Bharu, Kelantan. Kebanyakan responden ialah pelajar tahun ke 3 dengan (41.3\%), diikuti oleh pelajar tahun 1 dengan $(31.3 \%)$ dan selebihnya ialah pelajar tahun kedua dengan (27.5\%). Majoriti pelajar dengan (98.8\%) menggunakan bahasa Melayu sebagai bahasa ibunda mereka, sementara bakinya menggunakan bahasa Mandarin sebagai bahasa ibunda mereka (1.3\%). Jadual di atas juga menunjukkan bahawa (84.4\%) pelajar tanpa latar belakang bahasa Arab dan (15.6\%) pelajar yang mempunyai latar belakang bahasa Arab.

Jadual 2: Tahap Keseronokkan

\begin{tabular}{lcccc}
\multicolumn{1}{c}{ Perkara } & $\begin{array}{c}\text { Frekuansi } \\
(\mathbf{N})\end{array}$ & Purata (M) & $\begin{array}{c}\text { Sisihan Piawai } \\
(\text { SD) }\end{array}$ & Skor \\
\hline $\begin{array}{l}\text { Pembelajaran Bahasa Arab } \\
\text { menyeronokkan }\end{array}$ & 80 & 3.66 & 0.745 & Tinggi \\
\hline
\end{tabular}

Jadual 2 menunjukkan tahap keseronokan pelajar dalam pembelajaran bahasa Arab dengan skor purata (3.66). Kajian menunjukkan bahawa pelajar berasa seronok dan positif terhadap pembelajaran bahasa Arab walaupun mempelajari bahasa Arab bukan kursus wajib bagi program pendidikan awal kanak-kanak. Mereka mempunyai motivasi dan minat tinggi dalam mempelajari bahasa Arab.

Jadual 3: Kepentingan Multilingual

\begin{tabular}{ccccc}
\hline Perkara & $\begin{array}{c}\text { Frekuansi } \\
(\mathbf{N})\end{array}$ & Purata (M) & $\begin{array}{c}\text { Sisihan Piawai } \\
(\text { SD) }\end{array}$ & Skor \\
\hline Kepentingan Multilingual & 80 & 4.05 & 0.673 & Tinggi \\
\hline
\end{tabular}

Hasil kajian menggambarkan kebanyakan pelajar bersetuju bahawa pemerolehan bahasa Arab adalah penting dalam kalangan mereka dan mereka boleh menjadi orang berbilang bahasa dengan bahasa Melayu, Inggeris dan Arab. Lebih-lebih lagi, kebanyakan prasekolah 
menyediakan mata pelajaran bahasa Arab kepada kanak-kanak dan guru-guru perlu melengkapkan diri dengan kemahiran berbahasa Arab yang munasabah untuk menjalankan proses pengajaran dan pembelajaran.

Jadual 4: Kesungguhan Pelajar

\begin{tabular}{lcccc}
\hline \multicolumn{1}{c}{ Perkara } & $\begin{array}{c}\text { Frekuansi } \\
(\mathbf{N})\end{array}$ & Purata (M) & $\begin{array}{c}\text { Sisihan Piawai } \\
(\text { SD) }\end{array}$ & Skor \\
\hline $\begin{array}{l}\text { Kesungguhan Pelajar dalam } \\
\text { Mempelajari Bahasa Arab. }\end{array}$ & 80 & 3.57 & 0.823 & Tinggi \\
\hline
\end{tabular}

Jadual 4 menunjukkan hasil skor purata (3.57) iaitu mereka menunjukkan usaha mereka dalam mempelajari bahasa Arab. Responden bersedia untuk mengaudit subjek bahasa Arab kerana subjek itu bukan wajib kepada mereka berbanding program lain. Kajian ini juga menunjukkan hasil positif untuk menjadikan bahasa Arab sebagai mata pelajaran asas kepada program pendidikan awal kanak-kanak kerana bahasa Arab memberi manfaat kepada mereka dan membantu dalam proses pengajaran di sekolah prasekolah. Oleh itu, semakan semula keperluan pelajar dalam pendidikan awal kanak-kanak terhadap bahasa Arab adalah perlu bagi melengkapi para pelajar dengan bahasa ketiga.

Jadual 5: Kerjaya

\begin{tabular}{ccccc}
\hline Perkara & $\begin{array}{c}\text { Frekuansi } \\
(\mathbf{N})\end{array}$ & Purata (M) & $\begin{array}{c}\text { Sisihan Piawai } \\
(\text { SD) }\end{array}$ & Skor \\
\hline Nilai Tambah dalam Kerjaya & 80 & 3.93 & 0.823 & Tinggi \\
\hline
\end{tabular}

Berdasarkan Jadual 5, pelajar bersetuju bahawa bahasa Arab akan membantu mereka membina kerjaya mereka sebagai guru prasekolah. Keupayaan menguasai bahasa Arab akan menjadi nilai tambah kepada mereka sebagai graduan KPTM di samping memiliki Kumulatif (CGPA) yang sangat baik. Pada abad ke-21, memperoleh lebih daripada dua bahasa akan menjadi kelebihan kepada mereka yang mencari pekerjaan. Selain itu, kebanyakan prasekolah menyediakan subjek bahasa Arab tanpa mengira prasekolah agama atau prasekolah konvensional. Oleh itu, pelajar bersetuju bahawa bahasa Arab akan membantu mereka dalam melanjutkan kerjaya mereka sebagai guru prasekolah.

Jadual 6: Kepentingan Bahasa Arab

\begin{tabular}{ccccc}
\hline Perkara & $\begin{array}{c}\text { Frekuansi } \\
(\mathbf{N})\end{array}$ & Purata (M) & $\begin{array}{c}\text { Sisihan Piawai } \\
\text { (SD) }\end{array}$ & Skor \\
\hline Kepentingan Bahasa Arab & 80 & 4.05 & 0.809 & Tinggi \\
\hline
\end{tabular}

Para pelajar juga ditanya mengenai kepentingan bahasa Arab. Jadual 6 menggambarkan skor purata (4.05) yang menunjukkan bahawa pelajar bersetuju bahasa Arab penting terutama untuk memahami pendidikan Islam. Sebagai guru prasekolah, menguasai bahasa Arab untuk memahami istilah Islam penting untuk mengelakkan pemahaman yang salah dan pengajaran kepada anak-anak. Mengajar anak-anak membaca doa, iqra, dan asas fardhu ain merupakan salah satu tugas mereka. Oleh itu, bahasa Arab akan membantu mereka menjalankan tugas ini. 
Jadual 7: Pengasuhan

\begin{tabular}{lcccc}
\hline \multicolumn{1}{c}{ Perkara } & $\begin{array}{c}\text { Frekuansi } \\
(\mathbf{N})\end{array}$ & Purata (M) & $\begin{array}{c}\text { Sisihan Piawai } \\
(\text { SD) }\end{array}$ & Skor \\
\hline $\begin{array}{l}\text { Bahasa Arab penting bagi pengasuhan } \\
\text { kanak-kanak }\end{array}$ & 80 & 3.95 & 0.745 & Tinggi \\
\hline
\end{tabular}

Seperti yang disusun dalam Jadual 7, pelajar bersetuju bahawa bahasa Arab penting untuk penjagaan kanak-kanak dengan skor purata (3.95). Dalam konteks budaya Melayu, bahasa Arab penting untuk penjagaan kanak-kanak. Prasekolah Islam mendedahkan istilah Arab dalam kalangan kanak-kanak dalam membentuk sikap mereka. Selain itu, menguasai bahasa Arab juga sebagai persediaan untuk mereka menjalani pengajian program JQAF di sekolah rendah.

Jadual 8: Komunikasi

\begin{tabular}{lcccc}
\hline \multicolumn{1}{c}{ Perkara } & $\begin{array}{c}\text { Frekuansi } \\
(\mathbf{N})\end{array}$ & Purata $(\mathbf{M})$ & $\begin{array}{c}\text { Sisihan Piawai } \\
(\text { SD) }\end{array}$ & Skor \\
\hline $\begin{array}{l}\text { Bahasa Arab Penting untuk } \\
\text { Komunikasi }\end{array}$ & 80 & 3.86 & 0.775 & Tinngi \\
\hline
\end{tabular}

Berdasarkan jadual 8 di atas, hasil kajian menunjukkan majoriti pelajar bersetuju belajar bahasa Arab dapat membantu mereka berkomunikasi dengan bangsa Arab. Memandangkan Malaysia pada masa kini mempunyai banyak pekerja antarabangsa terutamanya dari negara-negara Arab seperti Sudan dan Arab Saudi, prasekolah juga merangkul kesan pendaftaran anak-anak berbangsa Arab terutamanya di prasekolah swasta. Oleh itu, penguasaan dan keperluan bahasa Arab boleh membantu mereka dalam mengajar anak-anak berbangsa Arab dan tidak mempunyai masalah untuk berkomunikasi dengan ibu bapa mereka.

\section{Bahagian B: Perspektif Guru}

Bahagian B menyediakan pandangan dari perspektif guru terhadap bahasa Arab dalam pendidikan awal kanak-kanak. Tujuh orang guru pendidikan awal kanak-kanak telah terlibat dalam kajian ini. Maklum balas daripada guru penting kerana dapat memberikan gambaran dan realiti yang jelas mengenai pentingnya bahasa Arab dalam bidang kerjaya. Data soalan jenis terbuka dianalisis dan diringkaskan dalam jadual di bawah:

Jadual 9: Latar Belakang Demografik

\begin{tabular}{cccccc}
\hline No & Jantina & Umur & Prasekolah & $\begin{array}{c}\text { Pengalaman } \\
\text { Mengajar }\end{array}$ & $\begin{array}{c}\text { Pengalaman Mengajar } \\
\text { Bahasa Arab }\end{array}$ \\
\hline 1. & Perempuan & 40 & Prasekolah Tg. Anis & 15 & Lebih dari 5 tahun \\
\hline 2. & Perempuan & 48 & Prasekolah Tg. Anis & 24 & Lebih dari 5 tahun \\
\hline 3. & Perempuan & 45 & Prasekolah Tg. Anis & 21 & Lebih dari 5 tahun \\
\hline 4. & Perempuan & 60 & Prasekolah At-Tarbiah & 32 & Lebih dari 5 tahun \\
\hline 5. & Perempuan & 53 & Prasekolah At-Tarbiah & 32 & Lebih dari 5 tahun \\
\hline 6. & Perempuan & 24 & Prasekolah At-Tarbiah & 2 & 1 tahun \\
\hline 7. & Perempuan & 32 & Al-Amin Tropicana & 2 & 1 tahun \\
\hline
\end{tabular}

Seperti yang ditunjukkan dalam jadual 9, 5 daripada 7 guru prasekolah mempunyai lebih daripada 15 tahun pengalaman dalam bidang pendidikan awal kanak-kanak dan semua guru prasekolah yang mengambil bahagian dalam sesi temu bual separa berstruktur ini ialah wanita. 
Majoriti mereka mempunyai lebih dari 5 tahun dalam mengajar bahasa Arab untuk kanakkanak. Jadual 10-13 menunjukkan pendapat guru tentang kepentingan bahasa Arab dalam kalangan bidang pendidikan awal kanak-kanak.

Jadual 10: Pandangan Guru Terhadap Kepentingan Bahasa Arab

\begin{tabular}{ll}
\hline Soalan 1: Kepentingan bahasa Arab di kalangan guru prasekolah. \\
\hline Guru 1 & $\begin{array}{l}\text { Bahasa Arab penting dalam kalangan pelajar prasekolah untuk mengetahui ayat al-Quran dan } \\
\text { menguasai teks Jawi. }\end{array}$ \\
\hline Guru 2. & $\begin{array}{l}\text { Sangat penting kerana bahasa Arab ialah bahasa al-Quran, bahasa syurga, oleh itu bahasa Arab } \\
\text { mesti dikuasai sepenuhnya oleh guru pendidikan awal kanak-kanak untuk diajar dalam prasekolah. }\end{array}$ \\
\hline Guru 3 & $\begin{array}{l}\text { Bahasa Arab penting kerana bahasa Quran ialah bahasa utama dalam zaman nabi dan bahasa ini } \\
\text { mesti dikuasai oleh semua guru prasekolah untuk mengajar Al-Quran dalam kalangan pelajar. Ia } \\
\text { juga sebagai persediaan untuk mendaftar di sekolah rendah. }\end{array}$ \\
\hline Guru 4 & Sangat penting sekurang-kurangnya guru dapat mengajar bahasa Arab asas. \\
\hline Guru 5 & Guru prasekolah mesti memperoleh bahasa Arab asas. \\
\hline Guru 6 & $\begin{array}{l}\text { Penting sekurang-kurangnya mereka dikuasai dalam komunikasi dan perbualan asas Arab dalam } \\
\text { kehidupan seharian. }\end{array}$ \\
\hline Guru 7 & $\begin{array}{l}\text { Bahasa Arab penting dan guru prasekolah harus mempraktikkan bahasa Arab dalam proses } \\
\text { pengajaran seperti memberi arahan, memuji dan mengajukan soalan }\end{array}$ \\
\hline
\end{tabular}

Berdasarkan jadual 10, kesemua guru prasekolah bersetuju dan sedar akan kepentingan bahasa Arab dalam bidang pendidikan awal kanak-kanak. Mereka juga mencadangkan sekurangkurangnya bakal guru prasekolah mesti menguasai komunikasi asas bahasa Arab bagi memudahkan PdPc di sekolah.

Jadual 11: Pandangan Guru Terhadap Sejauh Mana Penggunaan Bahasa Arab di Prasekolah

\begin{tabular}{ll}
\hline Soalan 2: & Sejauh manakah bahasa Arab digunakan dalam PdPc prasekolah. \\
\hline Guru 1 & $\begin{array}{l}\text { Bahasa Arab di prasekolah memberi tumpuan kepada bahasa Arab asas dan perkara-perkara di } \\
\text { sekeliling kanak-kanak. }\end{array}$ \\
\hline Guru 2 & $\begin{array}{l}\text { Fokus kepada bahasa Arab asas dan mudah untuk mengucapkan seperti keluarga, haiwan, dan } \\
\text { buah-buahan. }\end{array}$ \\
\hline Guru 3 & $\begin{array}{l}\text { Berdasarkan komunikasi bahasa Arab asas seperti ucapan iaitu dengan memberi tumpuan kepada } \\
\text { perolehan perbendaharaan kata seperti nombor, sayur-sayuran, buah-buahan dan keluarga. }\end{array}$ \\
\hline Guru 4 & $\begin{array}{l}\text { Fokus kepada komunikasi bahasa Arab asas supaya pelajar dapat memberi respon kepada arahan } \\
\text { yang diberikan dalam bahasa Arab. }\end{array}$ \\
\hline Guru 5 & Fokus kepada komunikasi asas mengenai alam sekitar di sekeliling mereka. \\
\hline Guru 6 & $\begin{array}{l}\text { Fokus terhadap komunikasi asas dalam kehidupan harian dan arahan asas yang digunakan di } \\
\text { prasekolah untuk membantu pelajar dalam proses pemerolehan perbendaharaan kata dan guru } \\
\text { dapat meningkatkan tahap sebutan pelajar. }\end{array}$ \\
\hline Guru 7 & $\begin{array}{l}\text { Murid terdedah kepada perbendaharaan kata yang biasa digunakan dalam rutin sekolah supaya } \\
\text { pelajar dapat memahami arahan yang diberikan, dan soalan yang ditanya oleh guru. Pelajar juga } \\
\text { boleh mengeja dan membaca kosa kata bahasa Arab. }\end{array}$ \\
\hline
\end{tabular}

Jadual 11 menunjukkan bahawa majoriti guru prasekolah positif terhadap penggunaan bahasa Arab kerana majoriti prasekolah di Malaysia mempunyai subjek bahasa Arab tidak mengira jenis praseolah sama ada kerajaan mahupun swasta. Guru mencadangkan kepada bakal guru prasekolah untuk menguasai asas perbendaharaan kata yang terdapat di sekeliling pelajar dari sudut empat kemahiran bahasa. 
Jadual 12: Pandangan Guru Terhadap Kelebihan Multilingual

\begin{tabular}{ll}
\hline $\begin{array}{l}\text { Soalan 3: } \\
\text { mempunyai kelebihan? }\end{array}$ \\
\hline Guru 1 & $\begin{array}{l}\text { Guru prasekolah mestilah membaca Al-Quran yang sangat baik kerana mereka akan mengajar mata } \\
\text { pelajaran Al-Quran serta subjek bahasa Arab dan akan menjadi kelebihan kepada mereka dalam } \\
\text { mencari pekerjaan. }\end{array}$ \\
\hline Guru 2 & $\begin{array}{l}\text { Guru mesti mempunyai keupayaan, mempunyai pembelajaran bahasa Arab asas, mampu membaca } \\
\text { al-Quran dengan baik kerana ia akan membantu proses pembelajaran bahasa Arab dengan lebih } \\
\text { berkesan. }\end{array}$ \\
\hline Guru 3 & $\begin{array}{l}\text { Guru dengan keupayaan berbilang bahasa akan menjadi keutamaan berbanding orang lain kerana } \\
\text { sebagai guru mereka harus mempunyai pelbagai pengetahuan yang berkaitan dengan pendidikan } \\
\text { awal kanak-kanak. }\end{array}$ \\
\hline Guru 4 & $\begin{array}{l}\text { Ya, kerana mereka akan mengajar Al-Quran dan mereka juga perlu lebih kreatif dalam mengajar } \\
\text { anak-anak. }\end{array}$ \\
\hline Guru 5 & $\begin{array}{l}\text { Ya, kerana guru yang mempunyai keupayaan berbilang bahasa terutama bahasa Arab boleh } \\
\text { menggalakkan pelajar dalam pembelajaran bahasa. }\end{array}$ \\
\hline Guru 6 & $\begin{array}{l}\text { Ya, sangat penting untuk menjadi guru dengan keupayaan berbilang bahasa (Bahasa Melayu, } \\
\text { Inggeris dan Arab) dan mereka harus dapat mengajar bahasa tersebut dalam kalangan kanak-kanak. }\end{array}$ \\
\hline Guru 7 & $\begin{array}{l}\text { Guru perlu menguasai bahasa asing dengan cemerlang kerana mereka akan mengajar bahasa asing } \\
\text { kepada pelajar. Mereka juga boleh menggalakkan pelajar belajar bahasa asing. }\end{array}$ \\
\hline
\end{tabular}

Berdasarkan jadual 12, guru prasekolah beranggapan bahawa individu berbilang bahasa mempunyai kelebihan dari aspek kerjaya dan profesion. Mereka mampu untuk mengajar bahasa di prasekolah di samping memberi dorongan dan galakan kepada pelajar untuk belajar bahasa Asing. Selain itu, kebolehan berbahasa Arab juga menjadikan pelajar mampu untuk mengajar subjek al-Quran kepada pelajar serta memberi pencerahan maksud yang betul.

Jadual 13: Pandangan Guru Terhadap Kebolehpasaran Graduan Berbahasa Arab

\begin{tabular}{ll}
\hline Soalan 4: Pada pendapat anda, menguasai bahasa Arab boleh meningkatkan peluang pekerjaan sebagai \\
guru prasekolah? \\
\hline Guru 1 & $\begin{array}{l}\text { Ya, kebanyakan graduan pendidikan awal kanak-kanak hanya mempunyai kelulusan akademik } \\
\text { sahaja walaupun sebahagian daripada mereka telah mempelajari bahasa Arab sebelum ini, mereka } \\
\text { tidak menguasai bahasa yang sangat baik. }\end{array}$ \\
\hline Guru 2 & $\begin{array}{l}\text { Kebanyakan sekolah di Malaysia mempunyai kesedaran tentang pentingnya bahasa Arab di } \\
\text { sekolah bukan sahaja di prasekolah, peluang kerjaya yang luas untuk guru pendidikan awal kanak- } \\
\text { kanak yang dapat mengajar bahasa Arab sebagai kemahiran bahasa nilai tambah selain Bahasa }\end{array}$ \\
& Melayu dan Bahasa Inggeris. \\
\hline Kuru 3 & $\begin{array}{l}\text { Kebolehan mengajar bahasa Arab adalah penting dalam pendidikan awal kanak-kanak kerana ia } \\
\text { adalah bahasa kedua di Malaysia sama seperti bahasa Inggeris. Selain itu, ia juga dapat } \\
\text { meningkatkan peluang pekerjaan di kalangan graduan kerana mereka menguasai lebih dari dua } \\
\text { bahasa. }\end{array}$ \\
\hline $\begin{array}{l}\text { Setuju, kerana kemampuan untuk mengajar bahasa Arab boleh menjadi kelebihan dan mempunyai } \\
\text { peluang pekerjaan yang lebih luas kerana kebanyakan graduan yang bekerja di prasekolah yang } \\
\text { mempunyai nilai tambah kerana mereka dapat meningkatkan kualiti prasekolah tersebut. }\end{array}$ \\
\hline Setuju kerana menguasai bahasa Arab mereka juga boleh mengajar mata pelajaran Al-Quran juga. \\
\hline Guru 5 6 & $\begin{array}{l}\text { Pada pendapat saya, seseorang yang mempunyai keupayaan berbilang bahasa bukanlah kriteria } \\
\text { utama untuk menjadi guru prasekolah yang baik. Seorang guru prasekolah yang baik mesti } \\
\text { mempunyai motivasi tinggi dan bersedia mempelajari sesuatu yang baru kerana mereka dapat } \\
\text { belajar bahasa Arab di kemudian hari. Itu sudah cukup untuk menolak calon dengan keupayaan } \\
\text { berbilang bahasa. }\end{array}$ \\
\hline $\begin{array}{l}\text { Setuju. Secara amnya, guru dengan bahasa Arab yang baik dapat mengajar Al-Quran dengan cara } \\
\text { yang lebih menarik. Selain itu, guru jenis ini berpotensi tinggi untuk menggalakkan pelajar } \\
\text { mencintai dan membaca Al-Quran. Oleh itu, guru prasekolah boleh membantu ibu bapa mendidik } \\
\text { anak-anak dalam persekitaran Islam serta meningkatkan pencapaian akademik. }\end{array}$ \\
\hline Guru 7
\end{tabular}


Berdasarkan dapatan di jadual 13, guru pra sekolah positif dan bersetuju bahawa individu berbilang bahasa mempunyai peluang kerjaya yang lebih cerah sebagai pendidik. Kebolehan berbahasa Arab bukan sahaja memberi peluang kepada guru untuk mengajar subjek bahasa Arab sahaja, bahkan mereka juga mampu dan berkebolehan untuk mengajar subjek al-Quran. Secara am nya, kebolehan berbahasa Arab bukanlan satu kriteria yang utama, ia adalah nilai tambah bagi kebolehpasaran graduan pendidikan awal kanak-kanak. Guru prasekolah yang mempunyai pengetahuan bahasa Arab dapat menjalan interdisiplin dan subjek seperti menghubungkait subjek matematik dengan bahasa Arab serta al-Quran. Hal ini menunjukkan bahawa kebolehan berbilang bahasa mampu meningkatkan kreativiti PdPc serta kualiti prasekolah.

\section{KESIMPULAN}

Analisis keperluan \& kepentingan bahasa Arab terhadap pendidikan awal kanak-kanak yang dijalankan memberi gambaran yang jelas terhadap kepentingan bahasa Arab dalam PdPc peringkat awal kanak-kanak di sekolah. Secara keseluruhannya, guru dan pelajar menganggap mata pelajaran bahasa Arab adalah satu subjek yang sangat penting perlu dikuasai oleh semua warga pendidik awal kanak-kanak dari segi peluang kerjaya kepada graduan, nilai tambah dan pengetahuan. Jelas bahawa bahasa Arab penting terutamanya dalam bidang pendidikan awal kanak-kanak kerana mereka juga boleh mengajar pelbagai subjek berteraskan bahasa Arab seperti al-Quran, Jawi, dan Fardhu ain kerana semua istilah dalam subjek ini berkaitan dengan bahasa Arab. Oleh itu, menguasai bahasa Arab tidak terhad untuk mengajar bahasa Arab sahaja tetapi guru dapat memenuhi subjek yang paling penting dalam prasekolah iaitu al-Quran.

Soal selidik kepentingan bahasa Arab telah menunjukkan keperluan pelajar jurusan pendidikan awal kanak-kanak menguasai bahasa Arab sebagai bahasa kedua atau bahasa ketiga adalah tinggi. Majoriti pelajar memerlukan kepada mata pelajaran khas yang perlu diambil sewaktu di pusat pengajian dalam membantu mereka mendalami bahasa Arab khususnya untuk mengajar di sekolah. Walau bagaimanapun, kajian lanjutan harus dijalankan yang melibatkan beberapa buah institusi pengajian tinggi yang lain untuk mendapat gambaran yang lebih menyeluruh berhubung isu ini. Kajian ini mencadangkan kepada penyelidik akan datang untuk mengkaji analisis keperluan pendidikan awal kanak-kanak dalam pembelajaran bahasa Arab dan mereka bentuk semula program pendidikan awal kanak-kanak dengan menambah mata pelajaran Bahasa Arab kerana subjek ini akan menjadi nilai tambah dan memberikan lebih banyak peluang pekerjaan di kalangan graduan.

\section{REFERENCES}

Adam, Z. \& Chick, A. R. (2011). Al Hajat Ila Daurah Al Lughah Al Arabiah Li Aghrad Al Siyahah Fi Malizia. Prosiding Seminar Antarabangsa Pengajaran Bahasa Arab 2011 (SAPBA'11) (pp. 320-332). Selangor: Universiti Kebangsaan Malaysia.

Adam, Z. (2013). Taalim Al Arabiah Li Aghradh Siyahiyah Fi Malizia: Tahlil Al Hajat Wa Tasmim Wihdat Dirasiah. Kuala Lumpur: Unpublished IIUM Phd Thesis, International Islamic University Malaysia.

Awang, N. A., Mohamed, M. H. \& Sulaiman, R. (2013). Enhancing Arabic Speaking Skills among Malay Students Through Group Work Activities. International Journal of Humanities and Social Science, 3(21), 212-219.

Azad, M. A. (1998). Taalim Al Lughah Al Arabiah Li Aghrad Khasah: Bina Wihdat Dirasiyah Li Tullab Al Takhassus Fi Al Aqidah. Kuala Lumpur: Unpublished IIUM M.A Dissertation, International Islamic University Malaysia. 
Chik, A. R. (1998). Teaching Arabic for Specific Purposes (ASP) with Special Reference to Teaching Reading Skill at the International Islamic University Malaysia. Unpublised M.A Dissertation University od Salford.

Daud, N. H. (1998). Taalim Al Arabiyyah Li Aghrad Ilmiyyah: Bina Wihdat Dirasiyyah Li Taalim Al Arabiyyah Lil Mutakhassisin Fi Al Fiqh. Kuala Lumpur: Unpublished IIUM M.A Dissertation, International Islamic University Malaysia.

Daud, W. A. (2016). Bina Wihdat Dirasiyyah Li Taalim Al Arabiyyah Li Dirasi Al Tiknulujiya Al Ziraiyyah Fi Kuliyyah Mara Lil Tiknulujiya Bi Wilayah Kalantan: Dirasah Wasfiyyah Tahliliyyah. Kuala Lumpur: Unpublished IIUM M.A Dissertation, International Islamic University Malaysia.

Daud, W. A. A. \& Ghani, M. T. A. (2016). Need analysis of agro technology students in learning Arabic Language at MARA Poly-Tech College (KPTM), Kelantan Darul Naim. National Conference of Research on Language Education 2016. Melaka: Universiti Teknologi MARA.

Ghani. M. T. A., Daud, W. A. A. \& Sahrir, M. S. (2016). Employing websites in language learning for tourism purpose among Arabic learners at the MARA College for Poly-Tech (KPTM). In Envisioning the Future of Online Learning. Spinger.

Hashim, H. (2010). Penguasaan kosa kata bahasa Arab program j-QAF dalam kalangan murid sekolah rendah. Selangor: Unpublished M.A Dissertation: Universiti Putra Malaysia.

Hutchinson, T., \& Waters, A. (2001). Key issues in English for specific purposes (ESP) curriculum development. The Internet TESL Journal.

Ismail, A. (2012). Tasmin Wihdat Dirasiah Li Taalim Al Arabiah Li Talabah Al Ulum Bi Al Jamiah Al Islamiah Al Alamiah Bi Malizia. Kuala Lumpur: Unpublished IIUM M.A Dissertation, International Islamic University Malaysia.

Jaafar, M. N. (2013). Tahlil Hajat Mutakhassisi Al Lughah Al Arabiah Wa Al Ittisalat Bi Jamiah Al Ulum Al Islamiah Al Maliziah Fi Taalum Al Lughah Al Arabiah Li Aghrad Siyahiayh. 4th International Conference of Arabic Language and Literature (ICALL 2013). Kuala Lumpur: IIUM Press.

Kadir, M. N. (2005). Tasmim Wihdat Dirasiah Li Taalim Al Lughah Al Arabiah Li Al Talabah Al Mutakhassisin Fi Al Syariah Al Islamiah Bi Kuliyyah Ahmad Ibrahim Li Al Qanun Bi Al Jamiah Al Islamiah Al Alamiah Bi Malizia. Kuala Lumpur: Unpublished IIUM M.A Dissertation, International Islamic University Malaysia.

Meyad, N. A., Roslan. S. Chong, M. \& Haji, B. (2014). The relationship between motivation and achievement toward studying Arabic grammar in Malaysia. International Conference on Arabic Studies and Islamic Civilization iCasic, (pp. 121-127). Kuala Lumpur.

Rahim, A. H. A., Ghani, M. T. A. \& Azhar, N. I. (2015). Need analysis of law Syariah students. National Conference on Arabic Language (pp. 407-420). Bangi: Institut Pendidikan Guru Kampus Pendidikan Islam.

Saleh, A. H. (2005). Tasmim Wihdat Dirasiyyah Lil Hujjan Wa Al Mutamirin Al Maliziyyin Fi Taalim Al Lughah Al Arabiyyah Li Aghrad Khassah. Kuala Lumpur: Unpublished IIUM M.A Dissertation, International Islamic University Malaysia.

Samah, R. (2007). Penggunaan internet dalam pengajaran bahasa: Kajian terhadap bahasa Arab komunikasi pelancongan. Malaysian Education Dean's Council Journal, 1(2), 83-95.

Shamsuddin, S. M. \& Ahmad, S. S. H. (2017). Contemporary issues of teaching Arabic in Southeast Asian countries (Brunei, Malaysia and Indonesia for The Example). Journal of Research in Humanities and Social Science, 5(6), 42-51.

Tu'aimat, R. A. (1989). Ta'lim al-Lughat al-'Arabiyyat Li Ghayr al-Natiqin Biha. Rabat: Mansyurat alMunazzamat al-Islamiyyat li al-Tarbiyyat waal-'Ulum wa al-Thaqafat (ISESCO).

Zainudin, G. (2010). Taalim Al Lughah Al Arabiah Li Aghrad Mihniah Li Talabah Al Tamridh Bi Kuliyyah Al Jamiah Al Islamiah Al Alamiah Bi Wilayah Salanjur: Dirasah Wasfiah Wa Tahliliah. Kuala Lumpur: Unpublished IIUM M.A Dissertation, International Islamic University Malaysia. 